\title{
WHAT DO EDUCATION STUDENTS THINK ABOUT THEIR ABILITY TO WRITE ESSAYS?
}

\author{
Gisela Consolación Quintero $\mathbb{D}$ \\ Universidad Nacional de Educación (Ecuador) \\ gishelinaq@hotmail.com
}

Received February 2018

Accepted March 2018

\section{Abstract}

The present study reflects the results obtained from a diagnosis carried out with Education students concerning the writing of academic essays. The objective was to identify the perceptions that Comprehensive Education students have about their ability to write academic essays. A descriptive cross-sectional research study was conducted at a single point in time, and in this case, in a single period or academic cycle, on the subject of written expression. In order to analyze the results from a mathematical-statistical perspective, descriptive statistics were used, in particular the calculation of the mean and the percentage analysis. The results showed that, of the 26 students, $50 \%$ rated themselves to have a fair level of essay writing ability. These self-assessment results do not correspond to the quality of the essays written by the students, who demonstrated a low level of essay writing ability. The practice of writing essays is a fundamental activity for the development of written communication at the university level; however, the teaching-learning process must be planned, since this type of writing is one of the most complex skills and has the greatest potential for explaining one's position and writing creatively. In no way can it be left in the hands of the students; it is necessary to formulate a different learning process that helps the students write essays of better quality.

Keywords - Writing, Academic Essay, Education Students.

\section{Introduction}

The difficulties that students have with academic writing are evident from the earliest stages of acquisition and persist until the age of adulthood (Mostacero, 2014). For years, it has become a problem that has not been solved and is closely related to educational success or failure, and as a result, to the scientific progress of society.

University classes do not teach students how to write, and much less how to write essays. However, they ask this of students as part of their academic activity. Academic essays are a type of text in which the epistemic function of writing is evident (Carlino, 2013; Cassany, 1999), as it presents a thesis and its corresponding arguments in an organized manner to convince other of one's own opinions.

Students reach the university level repeating and copying; when they manage to write, it requires great effort that does not always produce the best results. Therefore, writing essays is a skill for which they are not prepared (García \& Villegas, 2015) because no one has taught them. Writing remains a ubiquitous, but unobservable practice, and one that is demanded but is not commonly the subject of instruction, as argued by Carlino (2005).

There are various causes that play a part in this problem. Primarily, we can mention the lack of reading anything, much less essays. Students are not familiar with this type of text; therefore they do not know what an essay is, or 
its structure. They use means of connection inappropriately and they do not know how to give a thematic sequence and coherence to the text.

Another of the causes that has a decisive effect is the lack of interest students have in writing (García \& Villegas, 2015). This is because they are writing texts for non-existent readers and for an unknown context. Just like the students' writings have no basis in reality, they are also faced by a series of writing demands that are very different from those of the secondary school. They are no longer responding to literal questions, rather they are asked to write in another manner, with discursive skills that they do not have (Carlino, 2011).

According to a diagnostic study conducted by Lepe-Lira, Gordillo-Díaz and Piedra-Martínez (2011), students are capable of identifying the mistakes they make, but they do not know how to correct them. The studies mentioned above show some of the difficulties university students face and the arduous task that is represented by writing epistemically.

The problem not only has its causes in the previous training of students, but also in shortcomings in the instruction on the written text. We must remember that the product, and not the process, is still the most important. It is enough to simply observe how, who and what is corrected in a text. It has only been through research into text linguistics and academic literacy that writing has been given a primarily communicative importance, which has generated changes in how it is conceived, and thus in how it is taught (Carlino, 2011, 2012; Cassany, 1999; Roméu, 2014).

To these elements, we add another that is becoming increasingly more important in the academic field, which is that of revision and reflection on how writing is done. However, to review and correct, an instructor is required who teaches the students to revise their writings, who lets them talk about what they have written, and lets them feel like they can make mistakes and do not have to know everything. They must be educated so that they understand and write differently until they internalize the skill of writing and it forms part of their daily life.

Writing is a complex process that has gone from being a mega-skill to becoming a social practice. Its teaching-learning must therefore be provided at all educational levels, including at the university. It must become an integrated topic in any curriculum. This idea has already been proposed by Roméu (2014), while Carlino (2014) considers that it is necessary to write from the context of the courses. For this reason, for decades now in Australian and American universities, so-called academic writing centers or programs have existed as a way of helping solve the writing deficiencies of university students. For some strange reason, it is believed that upon reaching the university, students already know how to write, which is far from the truth.

In spite of the fact that the problem continues to grow, it does not seem to resolve itself; just the opposite, it is becoming increasingly worse. The problem is already known, as are some of its causes, and solutions are proposed, but the issue still exists. The question is why? And where is the solution? Some instructors neither read nor write to the extent that they should, and therefore, this begs the question: how can they teach students to write if they themselves do not? Why does one instructor ask students to write essays if he/she himself/herself has never written one? Both instructors and students are victims of the failure to teach writing. These ideas motivated the researcher to perform a diagnosis to explore the competence of Education students to write essays and how they perceive their own competence.

\section{Methodology}

\subsection{Research design}

The research design was that of a descriptive study measuring independent variables. In this regard, Arias (2012) states that its mission is to observe and quantify the modification of one or more characteristics in a group, without establishing any relationships among them (Arias, 2012: page 25). In other words, each characteristic or variable is analyzed autonomously or independently. The study was also cross-sectional, as it was conducted one single time, in this case in an academic period or cycle and in the Written Expression 
course. As a result, in this type of study, no hypotheses are formulated, but the presence of variables is obvious.

\subsection{Unit of observation}

The sample consisted of 37 students enrolled in the elective Written Expression course, selected via intentional non-probabilistic sampling (Arias, 2012: page 85). The participants were students enrolled in the seventh semester or later of the Comprehensive Education degree program. $86.5 \%$ were female and $13.5 \%$ were male. Of the 37 students, $70.3 \%$ were selected through intentional sampling, based on the following criteria:

Inclusion criteria

- Expressed agreement to participate in the study.

- Consent has been obtained from the student's parents or legal guardians for participation in the study.

- The student was registered in the course from the start of the semester.

- The student is not behind academically and has no outstanding courses pending at the start of the study.

Exclusion criteria

- Disagreement to participate in the study.

- Consent has not been obtained from the student's parents or legal guardians for participation in the study.

- The student was not registered in the course from the start of the semester.

- The student is behind academically or has outstanding courses pending at the start of the study.

\subsection{Operationalization of the variable}

The variable subject to study was the ability to write academic essays and it was conceived of by the researcher as a system of dialectically interrelated actions and operations for the construction of academic essays (Quintero, 2015).

\begin{tabular}{|c|c|c|c|c|}
\hline Dimension & Indicators & Items & Source & Instrument \\
\hline \multirow{8}{*}{$\begin{array}{l}\text { Competence to } \\
\text { write academic } \\
\text { essays }\end{array}$} & Types of texts that students write & 1 & \multirow{8}{*}{$\begin{array}{l}\text { Students in the } \\
\text { Education } \\
\text { degree program }\end{array}$} & \multirow{8}{*}{ Survey } \\
\hline & Essay definition & 2 & & \\
\hline & Steps for writing essays & 3 & & \\
\hline & Belief about the development of essay writing skill & 4 & & \\
\hline & Writing difficulties & 5 & & \\
\hline & Origin of the difficulties & 6 & & \\
\hline & Solution of the difficulties & 7 & & \\
\hline & Drafting of essays & 8 & & \\
\hline
\end{tabular}

Table 1. Variable: Essay writing

\subsection{Instrument}

A survey was designed with 8 questions that explored the students' skill in writing academic essays. It was drafted and validated in two ways. First, the content was validated based on expert opinion. Second, a pilot test was administered to test the behavior of the items and to check the construct validity based on factorial analysis. The results obtained from the pilot test were analyzed to ensure the reliability of the instrument. To do this, Cronbach's alpha reliability coefficient was calculated, which showed a result of 0.89225, which means that it is a reliable test (Palella \& Martins, 2012). 


\subsection{Procedure}

Informed consent was obtained from all participants. Next, on the second day of class, the survey was administered for the purpose of collecting information before the students had contact with the normal class activity, since it was a course in Written expression. The subjects were asked to evaluate their own skills on a Likert scale, using the system of actions involved in writing essays as a reference. Finally, to analyze the results from a mathematical-statistical perspective, descriptive statistics were used, in particular, the calculation of the mean and percentage analysis and the values on the scale given by the students on the survey questions were averaged to obtain percentage values.

\section{Results}

The results obtained on each of the survey questions are presented below.

\subsection{Types of texts that the students write most often}

The first inquiry conducted was in terms of the type of text most commonly written by the students in the degree program. In this regard, they stated the following: 15\% reports, $23 \%$ research, $50 \%$ essays, $8 \%$ monographs, $4 \%$ opinion articles. As shown, essays are the most frequent type of text students in this degree program are asked to write, which highlights the importance of their study.

\begin{tabular}{|l|c|c|}
\hline \multicolumn{1}{|c|}{ Type of texts } & Frequency & $\mathbf{0}$ \\
\hline Reports & 4 & $15 \%$ \\
\hline Research & 6 & $23 \%$ \\
\hline Essays & 13 & $50 \%$ \\
\hline Monographs & 2 & $8 \%$ \\
\hline Opinion articles Total & 1 & $4 \%$ \\
\hline & $\mathbf{2 6}$ & $\mathbf{1 0 0} \%$ \\
\hline
\end{tabular}

Table 2. Types of texts that the students write most often. Student survey

\subsection{What is an essay?}

The second question revealed that the students did not understand the concept of an essay. The answers to the question "What is an essay?" varied. Only one student came close to the concept, which represented $4 \%$ of the total; $8 \%$ stated that an essay was to give your opinion; another $8 \%$ said it was to inform; $12 \%$ believed that it is to collect information for a research work; $15 \%$ confused the concept of an essay with a summary; another $15 \%$ confused it with paraphrasing; $19 \%$ stated that it is to make a critique, but gave no information about the essence of the essay concept; and another 19\% stated that it is to express or portray ideas about a topic. These data are worrisome, given that of the twenty-six (26) students, only one came close to stating what an essay is. In spite of the fact that an essay provides information and includes criticism, the expression of ideas, opinion, paraphrases, and the summarizing and compilation of information; if a thesis is not presented that is justified by the author through arguments, it cannot be considered an essay.

\subsection{Procedure students follow when writing an essay}

In relation to this aspect, the procedure students followed was ascertained, paying particular attention to the actions and operations that the students carried out when writing an essay. The responses and their percentages were distributed as follow: $24 \%$ stated that the first thing that was necessary was to investigate in order to later draw conclusions and write down ideas and another $24 \%$ focused attention on the summary as the main action in an essay. $16 \%$ stated a sequence of actions that began with reading, but they did not mention the actions corresponding to writing an essay. $12 \%$ expressed the need to have prior knowledge of the topic. $8 \%$ mentioned planning; it is important to point out that it is the first action for writing an essay. $4 \%$ considered that an essay is written first with an introduction, then development and 
finally a closing. This student clearly understands the structure of this type of text, but did not state the actions to be taken to draft an essay. Another student (4\%) expressed the procedure as citing and supporting with arguments. Finally, only $8 \%$ presented a sequence of actions that approximated the drafting of an essay. By observing that of the total number of students, only $8 \%$ came close to what could be considered as a procedure to write essays, it is evident that the group of students does not know how to write an essay, in spite of the importance this type of text has in the Comprehensive Education degree program.

\subsection{Self-evaluation by the students regarding their ability to write essays}

One interesting result in the research on the students' perception of their level of ability to write essays was that $50 \%$ of those surveyed placed themselves at a fair level, $30 \%$ said they had a good level, $4 \%$ a very good level, $12 \%$ poor and $4 \%$ very poor (see Figure 1.) These data indicate that half of the group considers that they have certain limitations when it comes to writing a text, but that they are not that bad.

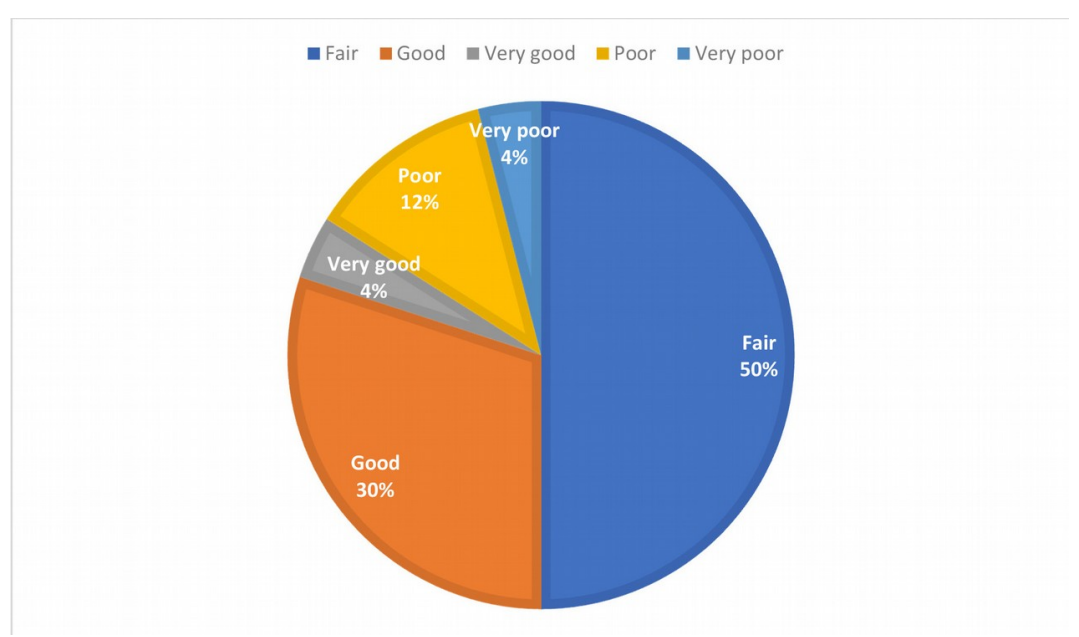

Figure 1. Self-evaluation by the students regarding their ability to write essays. Student survey

\subsection{Main difficulties in writing}

In this area, the main difficulties students perceived when writing an essay were related to accentuation and spelling. This percentage was the highest, at $60 \%$. This is followed by $20 \%$ for difficulties related to coherence and cohesion. Mostacero (2014) rightly warns that only the superficial aspects of writing are corrected, thus ignoring the most important elements of writing. What is not practiced in writing at school? The conditions and social contexts of social writing. These percentages show that, in the students' opinion, the main difficulties refer to language rules, giving less importance to discursive and pragmatic elements. In this regard, it is interesting to note that difficulties related to the pragmatic dimension of discourse are not even mentioned. The results are summarized in Table 3.

\begin{tabular}{|l|c|c|}
\hline Difficulties & Frequency & $\mathbf{\%}$ \\
\hline Difficulties related to accentuation and spelling & 16 & $62 \%$ \\
\hline Difficulties related to coherence and cohesion & 6 & $23 \%$ \\
\hline Lack of reading & 4 & $15 \%$ \\
\hline \multicolumn{1}{|c|}{ Total } & $\mathbf{2 6}$ & $\mathbf{1 0 0 \%}$ \\
\hline
\end{tabular}

Table 3. Main difficulties in writing. Student survey 


\subsection{Origin of the difficulties in essay writing}

As far as the origin of the writing difficulties students experience, the results were as follows: $37 \%$ attribute them to attitudinal aspects, such as carelessness or lack of interest. $9 \%$ state that the cause lies in the fact that they are not accustomed to reading, while 15\% believe it is due to lexical poverty. $19 \%$ state that the origin is due to the lack of knowledge and mastery of grammar rules and $12 \%$ say that it is the lack of a clearly established procedure for writing types of texts like essays. The answers showed a diversity of causes, referring precisely to the fact that the attitudinal aspect is most commonly considered to be the cause, above lack of knowledge and mastery of grammar. It is interesting to note that the aspect of teaching is not present.

\begin{tabular}{|l|c|c|}
\hline Origin of the difficulties & Frequency & $\mathbf{\%}$ \\
\hline Lack of knowledge and mastery of grammar rules & 5 & $19 \%$ \\
\hline Lack of a clearly established procedure for writing & 3 & $12 \%$ \\
\hline Students do not have the habit of reading and writing & 5 & $19 \%$ \\
\hline Ignorance of words. Lexical poverty. & 4 & $15 \%$ \\
\hline Attitudinal aspects: carelessness, impatience, laziness, lack of interest. & 9 & $37 \%$ \\
\hline Total answers & $\mathbf{2 6}$ & $\mathbf{1 0 0 \%}$ \\
\hline
\end{tabular}

Table 4. Origin of the difficulties in writing. Student survey

\subsection{Ways to overcome writing errors}

With regard to the possible solutions to reduce the difficulties in writing, $62 \%$ of the students expressed, first of all, that it was necessary to continuously practice reading. This percentage was the highest of all of them, which means that reading is considered to be the main route to better writing. Secondly, $12 \%$ referred to the continuous practice of writing and $12 \%$ to the use of dictionaries. In third place, the students indicated that the revision of what they write is an aspect to consider, with these responses accounting for $8 \%$. In fourth place, $3 \%$ of the students referred to the need to have a model and finally, one student stated that he/she did not know the solution. What is remarkable is that the students focused their answers on reading, in spite of the fact that they do not read. It is also interesting that they focus the path to a solution on themselves and not on other participants in the learning process, such as instructors. These results are very valuable in that they show that students are aware that their writing deficiencies in part lie within themselves and that they can overcome these difficulties with personal effort. The more delicate matter is that they do not know how to do it.

\begin{tabular}{|c|c|c|}
\hline Means of overcoming these problems & Frequency & $\%$ \\
\hline Reading a lot & 16 & $62 \%$ \\
\hline Constantly practicing writing & 3 & $12 \%$ \\
\hline Using a dictionary & 3 & $12 \%$ \\
\hline Revising what you write & 2 & $8 \%$ \\
\hline Having a clear model of an essay & 1 & $3 \%$ \\
\hline Does not know & 1 & $3 \%$ \\
\hline Total answers & 26 & $100 \%$ \\
\hline
\end{tabular}

Table 5. Ways to overcome writing difficulties. Student survey

\subsection{Writing an essay based on a topic of interest}

The writing samples by students evidenced isolated paragraphs with no thesis or reasoning; there was no local or global thematic sequence and multiple coherence errors. Obviously, it was evident that the students had not developed the skill of essay writing, in spite of the fact that they were studying at a 
professional level in a degree program and $50 \%$ of them rated themselves as fair in terms of this skill, as mentioned in question 4.

\section{Discussion}

Based on the results obtained, this work illustrates once again that in order to conduct intervention research in the field of education, it is worth first describing how the ideas students have about their own skills are presented and what influence they have. In the case of writing academic essays, as recognized by Domínguez (2006) and Castelló (2015), there are educational implications that are derived from these perceptions.

The data obtained in the study, in line with other international studies, reinforce the importance of improving the use of written language by university students. They need to create, with high standards of discursive production, academic texts that communicate effectively, concisely and directly their visions of the world, their contributions and their critical thought (Rijlaarsdam, Janssen, Braaksma, Van Teendam, Van den Branden \& Verheyden, 2013).

In spite of the fact that the survey results indicate that the students are aware of their main difficulties in writing and how to remedy them, according to them, they are primarily focused on the skill of reading. The concept of an essay is not clear to them, nor is its structure or the actions they must take to draft one. This creates difficulties when it comes to writing, since if a student does not know the structure of a text, it would be very difficult for him or her to conserve the macrostructural semantic and formal sequence of that text.

Of the responses given by the students, the author of this study gives greater significance to those related to the difficulties, their origin and ways to remedy them than to the perception they had of the level of their skill in writing essays. This is in light of the fact that the students are characterized by a low level of skill development, as demonstrated in the essays they wrote, and that did not match the results obtained from their self-evaluations.

These results demonstrated, on the one hand, the learning needs that the students have, and on the other hand, the deficiencies in the educational process that have not ensured true learning about the writing of essays, in spite of them being the top type of text most commonly required in the Comprehensive Education degree program at the university where the study was conducted. Therefore, there is a need to teach writing in any discipline and as a cross-curricular subject throughout the curriculum. To do this, instructors must integrate writing and reading exercises into their instruction, give lectures on the topic and write about what is read, and give specific guidelines on how the texts are written that the students are expected to write during the class. This cannot be left up to the language instructor and much less to the student.

The consolidation of skills to write academic essays will only be achieved if the instruction is systematic and provided in an organized manner, taking into account all the actions and operations that writing an essay requires (Quintero, 2015). This includes interviewing the students about what they want to write, since many times they have only a vague idea about the topic. But when students start to think, they provide answers that allow them to clarify their ideas. It is crucial to ask question after question until leading the students to realize that all the responses lie within themselves and there is no need to cut and paste.

The proposed new focuses for writing at the university level, a topic about which instructors and students have expressed their dissatisfaction, show that we have barely begun the long path in the search for answers to the problem of the poor ability to write academic essays that is evident in today's students. In many cases, these students have not been adequately prepared in the previous educational levels or lack the motivation needed to study and overcome difficulties. 
For the future, more studies are needed that are based on the linguistic-discursive analysis of studentwritten essays and use the methodology emanating from the linguistic analysis of the discourse (Castro \& Sánchez, 2013; Du Bois, 2014). A solid refresher is also needed for instructors in the subject of writing, so that they can teach how to write in their own classrooms in a way that is different from how they learned, because this is not writing.

\section{Conclusions}

- The practice of writing essays constitutes a fundamental activity for the development of written communication at the university level; however, its teaching-learning process must be planned, as writing of this type of text is one of the most complex skills with the most possibilities of proposing the author's position and for creative writing.

- One of the aspects that is interesting to note is that the students are only capable of identifying the traditional difficulties of spelling and accentuation, but they do not recognize those of greater importance for coherent writing, due to the lack of knowledge on the writing procedures and the little practice they have.

- Even though the data obtained in this study only confirm the reality that instructors see on a daily basis, it is imperative for academic writing to be taught systematically, with a communicative focus (Roméu, 2014).

- Since writing at the university has not been given the importance it requires and has not been considered as an epistemic skill that is directly related to social development; an educational process urgently needs to be proposed that includes the teaching of writing based on genres. Furthermore, it must form part of all courses in all degree programs.

\section{Declaration of Conflicting Interests}

The author declared no potential conflicts of interest with respect to the research, authorship, and/or publication of this article.

\section{Funding}

The author received no financial support for the research, authorship, and/or publication of this article.

\section{References}

Arias, F. (2012). El proyecto de investigación. Introducción a la metodología cientifica (6th ed. expanded and corrected). Caracas, Venezuela: Editorial Episteme. Available at: http://ebevidencia.com/wpcontent/uploads/2014/12/EL-PROYECTO-DE-INVESTIGACI\%C3\%93N-6ta-Ed.-FIDIAS-G.-ARIAS.pdf

Carlino, P. (2005). Prácticas y representaciones de la escritura en la universidad: los casos de Australia, Canadá, EEUU y Argentina. I Congreso Nacional de Estudios Comparados en Educación. Sociedad Argentina de Estudios Comparados en Educación, Buenos Aires. Available at: https://www.aacademica.org/paula.carlino/92.pdf

Carlino, P. (2011).¿Qué nos dicen las investigaciones internacionales sobre escritura en la universidad? In Democratización de la Universidad: Investigaciones y experiencias sobre el acceso y la permanencia de los/las estudiantes. Neuquén, Argentina: Educo (Ed. Universidad del Comahue).

Carlino, P. (2012). Escribir a través de curriculum: tres modelos para hacerlo en la universidad y una adenda. Cuadernos Pedagogicos, 1(1) 8-21. Available at: https://www.aacademica.org/paula.carlino/185.pdf

Carlino, P. (2013). Alfabetización académica diez años después. Revista Mexicana de Investigación Educativa, 18 (57), 355-381. 
Carlino, P. (2014). Se aprende muy diferente una materia si se lee y escribe sobre sus temas. En Serrano de Moreno, M.S., \& Mostacero, R. (Eds.), La escritura académica en Venezuela: investigación, reflexión y propuestas. Mérida, Venezuela: Universidad de Los Andes. Available at: https://www.aacademica.org/paula.carlino/214.pdf

Castelló, M. (2015). La investigación sobre escritura académica en los procesos de enseñanza-aprendizaje en la universidad española. Cultura y Educación, 27(3), 465-476. https://doi.org/10.1080/11356405.2015.1072362 Available at: https://dialnet.unirioja.es/servlet/articulo? $\operatorname{codigo}=5203979$

Cassany, D (1999). Construir la escritura. Barcelona. Spain: Paidós.

Domínguez, I. (2006). Modelo Didáctico para la orientación del proceso de construcción de textos escritos. Doctoral Dissertation. Ciudad de La Habana.

Du Bois, J. (2014). Hacia una sintaxis dialógica. 25(3), 259-410. Available at: https://doi.org/10.1515/cog-2014-0024

Castro, M., \& Sánchez, M. (2013). La expresión de opinión en textos académicos escritos por estudiantes universitarios. Revista mexicana de investigación educativa. 18(57), 483-506. Available at: http://www.scielo.org.mx/scielo.php?script=sci arttext\&pid=S1405-66662013000200008

García, L., \& Villegas, C. (2015). Lectura y escritura en la universidad: procesos fundamentales en la comunicación del conocimiento. REDHECS, 19(1).

Lepe-Lira, L.M., Gordillo-Díaz, R.Y., \& Piedra-Martínez, Y. (2011). La dificultad para escribir ensayos académicos. Un acercamiento desde la reflexión metacognitiva de estudiantes universitarios. XI Congreso Nacional de Investigación Educativa / 5. Educación y Conocimientos Disciplinares / Ponencia. Available at: http://www.comie.org.mx/congreso/memoriaelectronica/v11/docs/area 05/2245.pdf

Mostacero, R. (2014). Las dificultades de escritura en el contexto de una visión dialógica del discurso. Didáctica, 17, 4-15. Available at: http://erevistas.saber.ula.ve/index.php/legenda/article/viewFile/3920/3784

Rijlaarsdam, G., Jansen, T., Braaksma, M., Van Teendam, E., Van den Branden, K., \& Verheyden, L. (2013). Aprendizaje e instrucción en escritura (545-566). New York: Guilford Press. Available at: https://www.researchgate.net/publication/242756930 Rijlaarsdam G Jansen T Braaksma M Van Steendam E Van den Branden K Verheyden L 2013 Learning and Instruction in Writing In CA Stone ER Silliman BJ Ehren GP Wallach Eds Handbook of Language and Literac

Palella, S., \& Martins, P. (2012). Metodología de la Investigación Cuantitativa (3rd ed.). Caracas: Editorial Fedupel. Available at: https://metodologiaecs.files.wordpress.com/2015/09/metodologc3ada-de-la-investigacic3b3ncuantitativa-3ra-ed-2012-santa-palella-stracuzzi-feliberto-martins-pestana.pdf

Quintero, G. (2015). Sistema de Acciones y operaciones para escribir ensayos académicos. Sathiri, 8, 249-259. Indexed in Latindex, 2, 1955. ISSN 1390-6925. Ecuador.

Roméu, A. (2014). Periodización y aportes del enfoque cognitivo, comunicativo y sociocultural de la enseñanza de la lengua. Varona, 58, 32-46.

Published by OmniaScience (www.omniascience.com)

Journal of Technology and Science Education, 2018 (www.jotse.org)

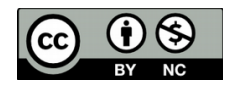

Article's contents are provided on an Attribution-Non Commercial 4.0 Creative commons International License. Readers are allowed to copy, distribute and communicate article's contents, provided the author's and JOTSE journal's names are included. It must not be used for commercial purposes. To see the complete licence contents, please visit https://creativecommons.org/licenses/by-nc/4.0/. 